\title{
Identification of fire changes using thermal IR images: the case of coal-waste dumps
}

\author{
by A. Abramowicz* and R. Chybiorz*
}

* Faculty of Natural Sciences, University of Silesia in Katowice, 41-200, Będzińska 60, Sosnowiec, Poland

\begin{abstract}
Coal-waste dumps' fires are a major environmental threat. They are usually subsurface fires, characterized by a long process and flameless combustion. This phenomenon is difficult to predict, locate, and eliminate. Current monitoring methods don't allow sufficient reaction to prevent the fire development

To better understand the phenomenon of dumps' fires, a series of aerial and ground thermal infrared photos were taken. They covered the area of a selected dump with active coal-waste fire. A comparative analysis of the obtained images in time and space was performed. Aerial photographs were compared to the ground ones. Trends in fire variability have been identified.
\end{abstract}

\section{Introduction}

Coal-waste dumps are anthropogenic forms of terrain built from hard coal waste. Many of them were set up ignoring the environmental consequences and all the principles of spatial planning [1]. Waste that builds the dumps often has a high content of organic material. Appropriate conditions can lead it to self-heating, which may then turn into environmentally dangerous subsurface fires [2]. This phenomenon is particularly often observed in coal basins, where many such facilities were built in a short time [3].

Various attempts are made today to fight the problem of burning dumps. One of them is the thermal monitoring of objects at risk [4]. Many methods of such monitoring have been already developed based on field, equipment, technical and financial conditions. The point method is one of the most popular and oldest ones. It involves a series of thermal measurements across the entire dump based on a regular or irregular grid of points, using pyrometers with probes. It is a relatively cheap method, but time-consuming and not very responsible (the holes made by the probe can aerate the dump, which can then increase the self-heating process) [5]. Non-invasive methods using infrared images have been alternatively used for dumps' monitoring [6]. These include satellite, aerial and terrestrial methods. Satellite images are the most convenient, remote, and global method. However, due to the low thermal resolution, they are not able to identify small fires. The obvious disadvantages include also the fact that the date and time of taking open-access satellite images are imposed, so the user has no influence over them [7]. Images took from a lower height using a drone have fewer restrictions [8]. In the case of such images, it is possible to plan the flight almost freely - adjust its height to the size of the object and determine the time of measurements. Unfortunately, the proper equipment (drone and thermal imaging cameras) is often very expensive. The terrestrial monitoring using only a handheld thermal imaging camera is an alternative method to satellites and drones [9]. It requires less equipment, but in many cases, the relief or land cover makes impossible to take proper pictures from the surface.

The article presents a comparison of aerial and terrestrial methods for thermal monitoring of coal-waste dumps. Identifying differences in obtained thermal values may improve the complex and long-term monitoring system. First of all, it can support the processing of data collected using several different methods, which can then facilitate a reliable comparison of all results.

\section{Methods}

Field studies were carried out on a selected object from the Upper Silesian Coal Basin (southern Poland). It is a coal-waste dump located in Ruda Śląska, built in 1990-2000. According to the literature, thermal phenomena appeared there already in 1995 [10].

Two infrared thermovision measurements were carried out on the dump on October 31, 2018, and March 29, 2019. The first stage of measurements consisted of a drone flight equipped with a FLIR Vue Pro $R 336$ thermal imaging camera (with 336x256 matrix, 7.5-13.5 $\mu \mathrm{m}$ spectral range, and $9 \mathrm{~mm}$ lens). The flights were carried out immediately before sunrise, with total cloud cover to avoid the cold sky effect [11]. The photos were taken from a height of $70 \mathrm{~m}$. The resulting images were appropriately processed in FLIR Tools and mosaic in AgiSoft software.

The second stage, made immediately after the first one, was based on taking a series of terrestrial photos using a FLIR T640 handheld thermal imaging camera (with 640x480 matrix, 7.5-14 $\mu \mathrm{m}$ spectral range, and $13 \mathrm{~mm}$ lens). Pictures were taken immediately after drone flight from a height of $150 \mathrm{~cm}$. Thermally active zones were identified in the field and photographed. Fire locations were recorded using a GPS device. The photos were processed in FLIR Tools software. 
Aerial and terrestrial photos were juxtaposed. A selected fire spot initially identified by geolocation was compared in both images. The obtained thermal values were analyzed. Correlation of received data was carried out. Differences between temperature values were identified.

\section{Results and discussion}

As a result of drone flights, two thermal maps were obtained and a series of fire zones were identified on them. For detailed analysis, one fire spot was selected (Fig. 1A - a). During the first flight, it was located on the technical road in the southern part of the dump, in a relatively flat area. The surface temperature directly above the fire ranged from $13^{\circ} \mathrm{C}$ to $24^{\circ} \mathrm{C}$, while the temperature of the thermally inactive zones was from $7^{\circ} \mathrm{C}$ to $12^{\circ} \mathrm{C}$ at an air temperature of $9^{\circ} \mathrm{C}$.

During the second flight, no thermal processes were identified at the location of the selected fire spot (Fig. 1B). However, a large fire was recorded 25 meters further in the south-west direction (Fig. 1B - c). Initially, it appears to be simply the next stage of a small fire also identified during the first measurement (Fig. $1 \mathrm{~A}-\mathrm{b}$ ). However, more thoroughly analyzing the course of the fire changes, including in particular the developed borderline and two fire centers, it can be clearly stated that the fire spot from the second flight is a combination of the previous two (Fig. 1A - a and b). This indicates the strong dynamics of thermal processes taking place on the dump.

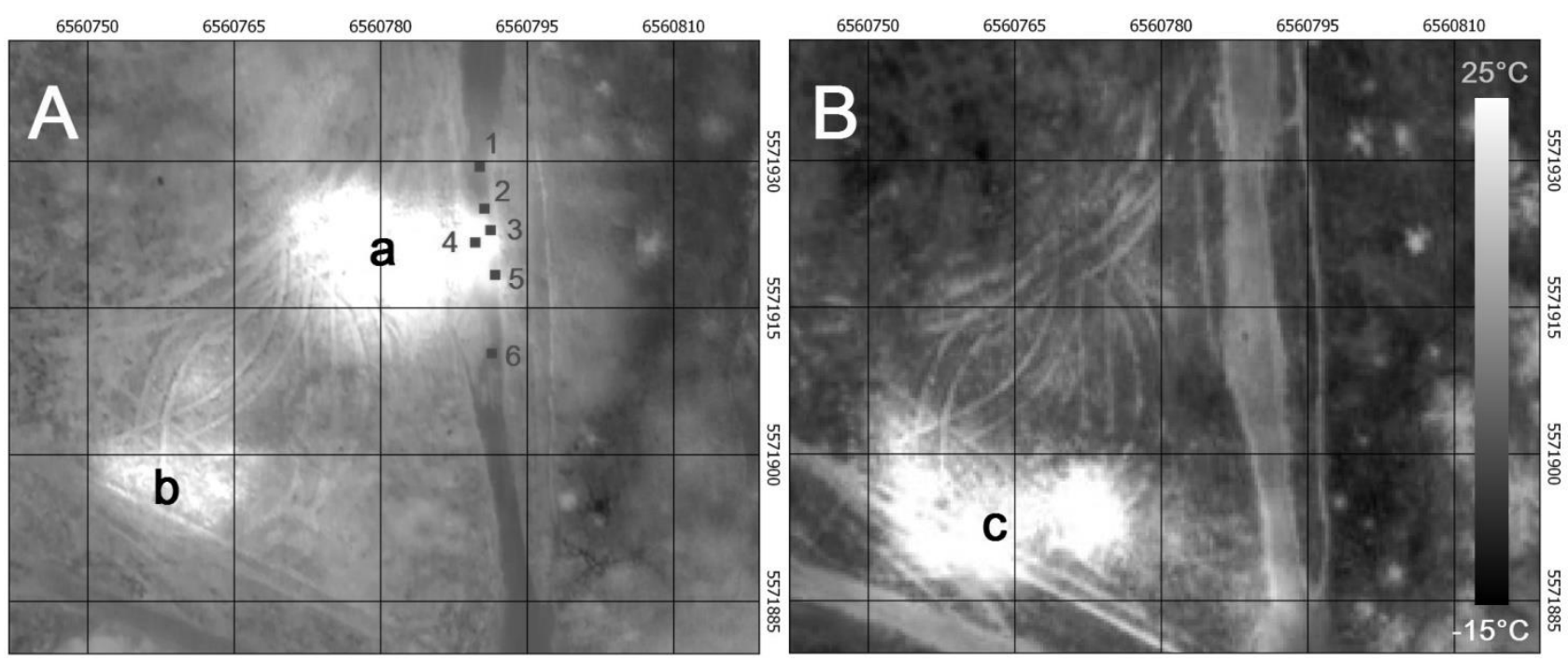

Fig. 1. Selected fire zone on the coal-waste dump in Ruda Śląska: $A$ - 31/10/2018, B - 29/03/2019.

Measurement points (see Fig. $2 \mathrm{~A}$ ): $1-10.5^{\circ} \mathrm{C}, 2-12.0^{\circ} \mathrm{C}, 3-16.5^{\circ} \mathrm{C}, 4-23.5^{\circ} \mathrm{C}, 5-16.5^{\circ} \mathrm{C}, 6-9.0^{\circ} \mathrm{C}$. Coordinate system: Poland CS2000, zone 6, EPSG: 2177.

Terrestrial images have detected the fire phenomena in the same places as aerial ones (Fig. 2). To compare them accurately, checkpoints were located along the road through which the previously selected fire zone passes (Fig. 1A, Fig. 2A). Their exact location was identified using GPS measurements. The obtained surface temperature values were compared with each other.

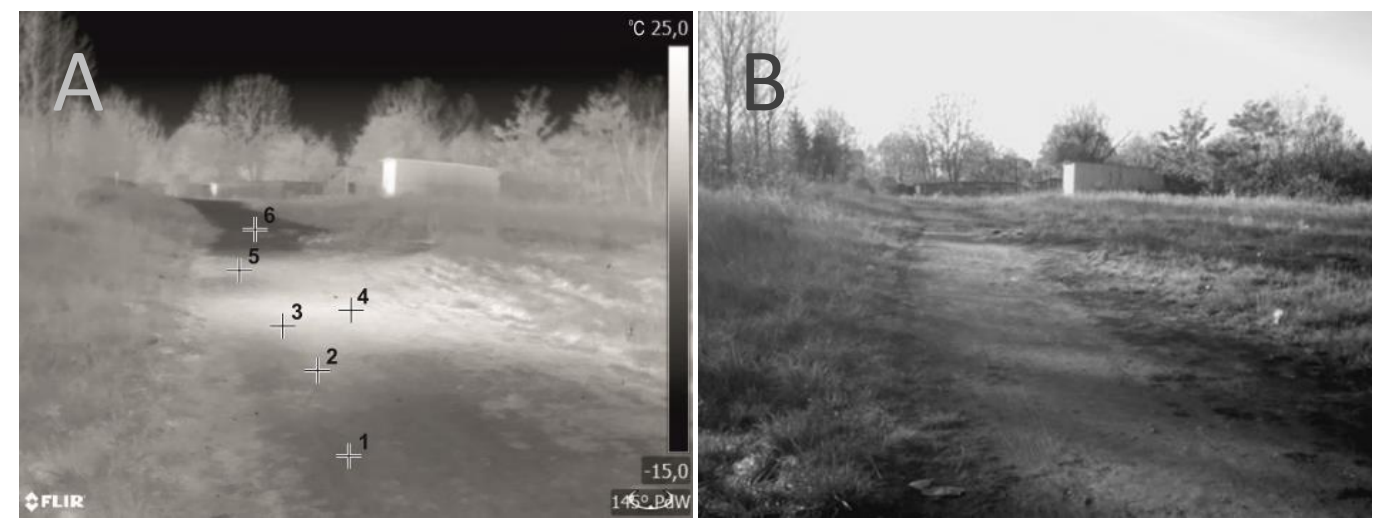

Fig. 2. Images from a handheld thermal imaging camera taken in the south direction: $A$ - in the infrared $\left(1-7.0^{\circ} \mathrm{C}\right.$, $\left.2-11.0^{\circ} \mathrm{C}, 3-16.0^{\circ} \mathrm{C}, 4-20.5^{\circ} \mathrm{C}, 5-13.0^{\circ} \mathrm{C}, 6-6.0^{\circ} \mathrm{C}\right), B-$ in visible light (31/10/2018). 
The differences in data obtained at six checkpoints using aerial (Fig. 1A) and terrestrial methods (Fig. 2A) ranged from $0.5^{\circ} \mathrm{C}$ to $3.5^{\circ} \mathrm{C}$. Higher values were always recorded in terrestrial images. These differences may result primarily from different distances from the measured place and a different angle of taking the picture. In the case of aerial images, the camera lens was directed to the surface at a right angle, while for terrestrial images the angle was acute. Despite the differences, Spearman's rank correlation [12] showed a very strong, positive relationship between the obtained temperature values (+0.986). It means that results from both methods have an equally well-identified burning area.

\section{Conclusions}

Infrared termovision is a perfect method for identifying thermal processes on coal-waste dumps. Infrared images can detect subsurface fires regardless of the height and angle from which they were taken, but thermal values obtained using aerial and terrestrial methods can be slightly different. The results of the research gave a preliminary view of the distribution of these differences in the case of an object with a flat surface and uniform land coverage. Identifying differences in other conditions requires further research and more checkpoints.

Fieldwork proved that it is much easier to predict the direction and rate of fire movement using aerial images. In the case of terrestrial ones, the main problem is to keep the constant height and angle for all photos. Determining the location of fire spots in geographical space based on aerial photographs is definitely easier rather than based on terrestrial images. It is mainly due to the inability to check the geolocation of objects from photos taken horizontally.

Knowledge of the differences between aerial and terrestrial thermal imagery may be of great importance in improving the monitoring methods for coal-waste dumps. First of all, it can affect comprehensive long-term monitoring based on several different methods. For such measurements, collective data analysis is usually necessary, regardless of the method and time of data collection. Therefore, a method of compiling and converting data in a way that makes it comparable is required. The implementation of a certain algorithm can increase the interpretation potential of large thermal data sets. An attempt to create such a procedure will be made in further researches.

\section{REFERENCES}

[1] Szczepanska, J., Twardowska, I., Distribution and environmental impact of coal-mining wastes in Upper Silesia, Poland, Environmental Geology, vol. 38, pp. 249-258,1999.

[2] Ciesielczuk J., Misz-Kennan M., Hower J.C., Fabiańska M.J., Mineralogy and geochemistry of coal wastes from the Starzykowiec coal-waste dump (Upper Silesia, Poland), International Journal of Coal Geology, vol. 127, pp. 42-55, 2014.

[3] Gawor Ł., Coal mining waste dumps as secondary deposits - examples from the Upper Silesian Coal Basin and the Lublin Coal Basin, Geology, Geophysics and Environment, vol. 40, no. 3, pp. 285-289, 2014.

[4] Wasilewski S., Skotniczy P., Mining waste dumps - modern monitoring of thermal and gas activities, Gospodarka Surowcami Mineralnymi - Mineral Resources Management, vol. 31, no. 1, pp. 155-182, 2015.

[5] Abramowicz A., Chybiorz R., Fire Detection Based on a Series of Thermal Images and Point Measurements: the Case Study of Coal-Waste Dumps, International Archives of the Photogrammetry, Remote Sensing and Spatial Information Sciences, vol. XLII-1/W2, pp. 9-12, 2019.

[6] Huo H., Ni Z., Gao C., Zhao E., Zhang Y., Lian Y., Zhang H., Zhang S., Jiang X., Song X., Zhou P., Cui T., A Study of Coal Fire Propagation with Remotely Sensed Thermal Infrared Data, Remote Sensing, no. 7, pp. 3088-3113, 2015.

[7] Nádudvari Á., Thermal mapping of self-heating zones on coal waste dumps in Upper Silesia (Poland) - A case study, International Journal of Coal Geology, vol. 128-129, pp. 47-54, 2014.

[8] Surovka D., Pertile E., Dombek V., Vastyl M., Leher V., Monitoring of thermal and gas activities in mining dump Hedvika, Czech Republic, IOP Conference Series: Earth and Environmental Science, vol. 92, 2017.

[9] Korski J., Thermovision in monitoring and coal waste dump fires extinguishing (in Polish), Górnictwo i Geologia, vol. 5, no. 2, pp. 91-103, 2010.

[10] Łączny J.M., Baran J., Ryszko A., Opracowanie i wdrażanie innowacyjnych technologii środowiskowych stosowanych na zwałowiskach odpadów powęglowych, Wydawnictwo Naukowe Instytutu Eksploatacji - PIB, p. 300, 2012.

[11] Nowak H., The influence of environmental thermal radiation on the results of thermographic investigation of buildings (in Polish), Budownictwo i Architektura, vol. 12, no. 3, pp. 59-66, 2013.

[12] Gautheir T. D., Detecting Trends Using Spearman's Rank Correlation Coefficient, Environmental Forensics, vol. 2, no. 4, pp. 359-362, 2001. 